\title{
Dobre słowo jako tekst magiczny. Życzenie — pozdrowienie błogosławieństwo
}

\section{Błogosławieństwa, życzenia i pozdrowienia jako wzorce zachowań rytualnych}

Życzenia, błogosławieństwa, pozdrowienia należą do skonwencjonalizowanych tekstów ustnych stosowanych zwłaszcza w bezpośredniej komunikacji. Komunikowanie dobrych intencji $\mathrm{w}$ interakcji $\mathrm{z}$ innymi członkami społeczeństwa należy do archaicznych form zachowań rytualnych, w których współdziałanie słowa i gestu jest na tyle silne, że niekiedy dochodzi do ich wymiennego stosowania (sam gest przywołać może konotacje werbalne, a słowo zastąpić towarzyszący mu zwyczajowo gest). Formuliczność tekstu oraz rutynowy wzorzec zachowań, charakteryzujące działania magiczne, czynią zeń prototypowy tekst kultury, głęboko zakorzeniony w społecznej świadomości ${ }^{1}$. Pamięć zbiorowa przechowuje zarówno schematy przedpojęciowego myślenia, opartego na kognitywnym doświadczeniu i interpretowaniu świata ${ }^{2}$, jak też symbole, mające swe źródło w rytualnym sposobie przeżywania mitu, polegającym na powielaniu boskich gestów. Obrzędowo-rytualne powtarzanie demiurgicznych gestów reaktywuje znaczenie

${ }^{1}$ Marta Wójcicka sformalizowany tekst ustny traktuje jako prototypowy tekst kultury, konstytuujący pamięć zbiorową (2014, s. 58-70). Zgodnie z klasyfikacją rytuałów słownych, zaproponowaną przez Annę Engelking, operowanie „dobrym słowem” należy do rytuałów stwarzających (Engelking 1991, s. 77-80).

2 Według założeń nurtu kognitywistycznego poznanie, interpretacja i konceptualizacja rzeczywistości oparte są na fizycznym, emocjonalnym i psychicznym doświadczeniu człowieka w interakcjach ze światem zewnętrznym. Koncepcję schematów przedwyobrażeniowych zaproponował kontynuator nurtu kognitywistycznego Mark Johnson w pracy The Body in the Mind. The Body Basis of Meaning, Imagination and Reason (1990), a na gruncie polskim upowszechnił ją Tomasz Krzeszowski (1994). Teorię tę zastosowała i rozwinęła Agnieszka Libura (2000). 
symbolu. Moc absolutna, właściwa tylko istocie boskiej, staje się wówczas udziałem człowieka, a wypowiedziane słowo nabiera mocy sprawczej (Campbell 1994, s. 95; Eliade 2000, s. 477; Lurker 1994, s. 9, 27; Masłowska 2012a, s. 34).

Sięganie do symbolu, wyrastającego z mitu, stanowi nieuświadamiany bagaż kulturowego dziedzictwa, zachowanego w gestach i słowach. Jednakże w procesie transmisji międzypokoleniowej tradycyjne wzorce podlegają aksjologicznej selekcji oraz adaptacji do potrzeb nowoczesności. Tradycja rozumiana jako proces kulturotwórczy polega na nieustannej konfrontacji zastanych wzorców (zasobów pamięci) ${ }^{3}$ ze zmieniającą się rzeczywistością (Nahodil 1991, s. 5-17; Szacki 1971, s. 97, 108; Wójcicka 2014, s. 59).

Rekonstrukcja łańcucha zmian, jakim podlegały dobre słowa-zaklęcia, symboliczne gesty, jak też same formuły magiczne oraz scenariusze działań, prowadzi do ukazania konceptualizacyjnych i kulturowych podstaw kodów zachowań. Instrumentarium analityczne, jakie posłuży do zilustrowania omawianego procesu, opiera się na pamięci semantycznej symbolu (odwołującego się do mitu, a reaktywowanego w rytualnej scenie błogosławieństwa lub składania życzeń), leksyki (jej archaicznego znaczenia etymologicznego i konotacji) oraz aksjologii — głównego kryterium selekcjonującego, decydującego o kierunku zmian.

Sieć powiązań semantycznych, w jaką wpisane są rytualne słowa, gesty i symbole składające się na kulturowe teksty życzące (życzenia, błogosławieństwa i pozdrowienia), przedstawię na przykładzie scen, w których „dobre słowo” i towarzyszące mu gesty stanowią podstawę scenariusza ${ }^{4}$. W schemat praktyk magicznych wpisane są działania ochronne, zabezpieczające przed ingerencją sił nieczystych, które mogłyby zakłócić realizację dobrego życzenia, wbrew intencji nadawcy. Ochronne kody zachowań w sposób istotny uzupełnią analizę scenariuszy życzeniowych. Odwołanie się do zasobów społecznej pamięci kulturowej, operującej stereotypowymi scenami, w których dobre słowa nabierają magicznej mocy i urzeczywistniają się, pozwoli na dotarcie do ich semantycznego jądra oraz kulturowego prototypu scenariusza życzeniowego i ochronnego oraz ich językowych wykładników.

${ }^{3}$ Otakar Nahodil określa tradycję jako pamięć kulturową, która stanowi bazę doświadczeniową przekazywaną nowej generacji przez zstępujące pokolenie, wskazując jednocześnie na jej twórczy potencjał. Innowacyjny charakter tradycji polega na tym, że wartości przejęte w drodze transmisji zyskują nową jakość (Nahodil 1991, s. 16-17).

${ }_{4}$ Model konstruowania sceny opieram na Langackerowskiej koncepcji łańcucha energetycznego (Langacker 2009, s. 473). Przyczynowo-skutkowa struktura zdarzenia, podczas którego uczestnicy przekazują sobie energię, determinuje ich pozycje na scenie i profiluje role archetypowe: agensa (inicjatora zdarzenia), instrumentu (przekaźnika energii), pacjensa (odbiorcy) lub tła scenerii. W każdej scenie będziemy mieć do czynienia z profilowaniem ról o różnym stopniu aktywności, zależnie od pozycji na scenie i funkcji w łańcuchu energetycznym. Najbardziej prototypowa jest rola agensa - inicjatora przepływu energii, najmniej — funkcja instrumentu lub odbiorcy (Kardela 1998, s. 81-84; Langacker 2009, s. 473; Tabakowska (red.) 2001, s. 114-119). 


\section{Słowo i gest w aktach błogosławieństwa}

Za punkt wyjściowy dalszych analiz przyjmuję prototypową scenę błogosławieństwa, opartą na scenariuszach pożegnalnych, w których ochronnym słowom-zaklęciom towarzyszą konwencjonalne gesty — pocałunku i/lub znaku krzyża, w zależności od okoliczności, przybierające różne formy. $\mathrm{W}$ okresie staropolskim funkcję magiczną spełniała formuła pożegnalno-powitalna ceł, cat 'bywaj zdrów' (= wracaj zdrowy i cały). Prototypowym scenariuszem byłoby pożegnanie bohatera udającego się w niebezpieczną podróż, na wojnę lub polowanie. Pożegnanie ,dobrym słowem”, wzmocnione gestem pocałunku (prototypowo w usta) oraz znakiem krzyża (zakreślonym na głowie żegnanego lub w powietrzu za odchodzącym), miało mu zapewnić bezpieczny powrót do domu w nienaruszonym stanie, por. stp. caleć 'wychodzić cało z niebezpieczeństwa', calić 'ochraniać, zachować w całości', a także dzisiejsze ocalić (Długosz-Kurczabowa 2005, s. 62).

Podstawę konceptualizacyjną scenariusza stanowią przedpojęciowe preschematy wyobrażeniowe CZĘŚĆ-CAŁOŚĆ (odwołanie do doświadczenia integralności ludzkiego ciała) oraz podlegle mu domeny WIĘZI i KONTROLI. Przekonanie o skuteczności zaklęcia ma swe źródło w micie początku — geście kreacyjnym - tchnięcia życia w nozdrza człowieka oraz stwórczej mocy słowa (Kopaliński 1990, s. 327). Powielenie boskiego gestu stwórczego oznacza wiarę w uzyskanie dostępu do mocy sacrum, co oddaje preschemat SIŁY — zasadniczy składnik wszystkich działań magicznych.

Językowa formuła powitalno-pożegnalna cet, cat wchodzi w sieć powiązań semantycznych derywatów utworzonych na bazie przymiotnika cały: całość 1. 'komplet, ogół części'; 2. 'zdrowie' (każdy dba o swoja całość, poświadczone u Lindego z XVII wieku), całować "pozdrawiać" , poświadczone od XVI wieku (Długosz-Kurczabowa 2005, s. 62). Łańcuch powiązań między symbolicznym gestem pocałunku a werbalnymi formułami „dobrego słowa” w postaci pozdrowień, powitań, zawierających w swej strukturze życzenie zdrowia, ukazują zarówno słowiańskie, jak i indoeuropejskie etymologie verbum całować: cz. celý, ros. céłyj, sch. cïjel, scs cělı 'zdrów', 'cały', cz. celovati 'ts', też 'goić, uzdrawiać, scalać'. Pierwotne znaczenie scs cělovati 'pozdrawiać', por. goc. halis 'witaj', sgniem. Heiazzen, stprus. kailüstiskan, 'pozdrawiać', stprus. kails — patis kails 'zdrów' (Sławski 1983, s. 54).

Zarówno znaczenia, jak i konotacje tekstowo-wyobrażeniowe, jakie rozwinęły się wokół leksemu cały oraz verbum całować, koncentrują się wokół zdrowia. Zdrowie jako atrybut życia mieści się w kategorii wartości witalnych, ocenianych

5 Językowemu obrazowi zdrowia, opartemu na pojęciu całości, przeciwstawia się konceptualizacja choroby jako dezintegracji (por. leksemy obrazujące chorobę: próchnieć, gnić, sypać się — Marczewska 2014, s. 154-155; Masłowska 2004, s. 183-184). Również Bogumił Samuel Linde definiuje zdrowie w opozycji do choroby (1951, s. 1199), podobnie czynią współcześni słownikarze, co szczegółowo omówiła Ewa Wolnicz-Pawłowska (2004, s. 157-160). 
przez ludzi jako to, co dobre, pożądane, godne starań i zachowania. We wszystkich językach świata waloryzowane jest dodatnio (Wolnicz-Pawłowska 2004, s. 153). Stąd wysoka wartość aksjologiczna, jaką przypisano zdrowiu, znajduje wyraz zarówno w formule dobrego życzenia, jak i w symbolicznym geście pocałunku.

Proces zmian, jakim podlegał słowny rytuał pożegnalny, obejmował bądź zmianę formuły (cet cat > bywaj zdrów, wracaj zdrów $i$ cały), bądź eliminację funkcji słowa przejmowanej przez wymowne gesty pocałunku (= życzeniu zdrowia) oraz znaku krzyża, symbolizującego powierzenie bohatera opiece boskiej (w znaczeniu ocalenia od niebezpieczeństw). Natomiast werbalizacja znaku krzyża w postaci frazemu krzyżyk na droge zasadniczo zmienia pierwotny sens błogosławieństwa na rzecz zakomunikowania zerwania więzi (w znaczeniu ,idź i nie wracaj”), choć pierwotna treść (niech cię Bóg ma swojej opiece) jest tu szczątkowo zachowana.

Natomiast gest kreślenia krzyża w kanonicznym akcie błogosławieństwa wiernych na zakończenie odprawiania liturgii mszy świętej, któremu towarzyszy formuła słowna Niech was błogosławi Bóg Ojciec, Syn i Duch Święty, idźcie w pokoju, ofiara skończona, w pełni zachowuje symbolikę właściwą wszystkim znakom sakralnym, przez które ,urzeczywistnia się uświęcenie człowieka, a Bóg otrzymuje całkowity kult publiczny" (Konstytucja Liturgii 7, cyt. za: Sinka 1994, s. 73, 74). W scenerii liturgicznej sacrum zajmuje miejsce naczelne, podczas gdy pozostali uczestnicy — wierni wraz z kapłanem — zajmują pozycję drugorzędną: celebrans jako przekaziciel, a wierni jako odbiorcy mocy. Symbolika znaku liturgicznego obejmuje cztery wymiary: przypominający (że znak działa, dzięki mocy zbawczego dzieła Chrystusa), oznajmujący (uświęcające działanie łaski Bożej), zobowiązujący (do życia chrześcijańskiego) oraz zapowiadający (liturgię niebiańską) (Sinka 1994, s. 74). Przyjęcie błogosławieństwa stanowi akt wiary, z czego wynika poczucie powinności moralnej — uznania kanonu religijnych wartości.

Konceptualizacja błogosławieństwa w języku kultu opiera się wprawdzie na tych samych preschematach wyobrażeniowych, co w języku świeckim, jednakże wyprowadzane z nich ścieżki kognitywne mają inny przebieg, łącząc znak krzyża z łaską, odkupieniem i życiem wiecznym (Forstner 1990, s. 13). Preschematy CAŁOŚCI, WIĘZI budują syntetyczny obraz łączności między światem sacrum a profanum. Znak krzyża w liturgii nie ulega przeobrażeniom i przewartościowaniom - w przeciwieństwie do świeckich sposobów posługiwania się tym gestem.

Do aktów błogosławieństwa należy też symboliczny gest ceremonialnego ucałowania ziemi i rodzinnego progu, przywołany przez papieża Jana Pawła II podczas pielgrzymki do ojczyzny. Symbolika papieskiego gestu powitalnego ma bardziej złożony charakter, choć w swej podstawowej strukturze zawiera archetypowe znaczenie pozdrowienia i błogosławieństwa. Papieski sposób oddania hołdu ojczystej ziemi i rodzinnemu domostwu odnosi się do znacznie szerszego kontekstu - świętości ziemi, a także bogatej symboliki domu i progu jako granicy swojej i świętej przestrzeni oraz tradycyjnych wartości rodzinnych (sza- 
cunku dla rodziców i domu), a także uczuć patriotycznych (Bartmiński 2009, s. 149-150). Przypomniany przez Ojca Świętego tradycyjny wzorzec zachowania syna powracającego do rodzinnego domu wskazuje na trwałość tekstów kultury oraz ich zdolność do odradzania się i przetwarzania. Pocałunek ziemi i progu — choć archaiczny w swej treści i symbolice — został odebrany jako czytelny wyraz czci, synowskiej miłości, wierności, oddania i dziękczynienia (Masłowska 2012b, s. 134-135). Symbolika gestu ucałowania ziemi (nie tylko ojczystej) przez papieża zastępuje werbalny akt powitalnego błogosławieństwa, w sposób syntetyczny łącząc profanum z sacrum. Ścieżki kognitywne wywodzące się z preschematów CAŁOŚCI i WIĘZI tworzą semantyczną sieć powiązań między pocałunkiem a łaską, niebem, ziemią i domem. W scenie ceremoniału powitania ziemi Ojciec Święty zajmuje miejsce centralne, choć jest tylko przekazicielem Bożej łaski, podczas gdy sacrum — właściwe źródło mocy — obecne jest w tle sceny. Odbiorcami błogosławieństwa są święta ziemia, dom rodzinny oraz ich mieszkańcy.

\section{Gest zastępujący słowo w działaniach magicznych}

Pamięć etymologicznego znaczenia całować 'scalać, goić, uzdrawiać' zachowują sceny powszechnie znane $\mathrm{z}$ bajek o śpiącej królewnie oraz księciu zaklętym w żabę. W obu wypadkach magiczny pocałunek ma ożywczą moc - wybudza ze snu królewnę uznaną za zmarłą, a księciu przemienionemu w gada przywraca ludzką postać. W paralelnych obrazach mamy też do czynienia z ekwiwalentną funkcją symbolicznego gestu w stosunku do słowa. Ożywiający gest nawiązuje do boskiego tchnienia, włączając pocałunek w ciąg semantyczny śmierć - życie — zdrowie - pocałunek. Pamięć komunikacyjna przechowująca pełen kontekst sytuacyjny działania magicznego (słowa i gestu) pozwala na prostą transformację zaklęcia w symboliczny gest. Znane z życia codziennego praktyki stosowania ,gojącego pocałunku" matki na zranienia dziecka oraz ich kojący skutek mają analogiczne źródło, co motywy bajkowe. Nawiązują też do tych samych preschematów - CAŁOŚCI, WIĘZI, KONTROLI oraz SIŁY (Masłowska 2012b, s. 133-134).

Pamięć etymologiczna pocałunku, nawiązująca bezpośrednio do znaczenia podstawy derywacyjnej cały, ujawnia się także w scenie całowania kart przed przystąpieniem do gry - magiczny pocałunek lub gest chuchnięcia (oba odwołujące się boskiego gestu stwórczego) mają ocalić bohatera przed przegraną. Analogiczną funkcję spełnia zwyczaj całowania ostrza miecza/szpady przed pojedynkiem. W obu przypadkach dobre życzenie bohater kieruje w stosunku do samego siebie, jest więc jedyną i centralną postacią na scenie, łącząc rolę przekaziciela i odbiorcy mocy, a odwołanie się do sił nadprzyrodzonych wskazuje na obecność sacrum w tle sceny (Masłowska 2012b, s. 134). 


\section{Pozdrowienia i życzenia jako słowne akty sprawcze}

Magiczna funkcja pocałunku, gestu uściśnięcia dłoni, skinięcia głową lub ręką w połączeniu z powitalną formułą życzącą dzień dobry, dobry wieczór (stosownie do pory dnia), poddana próbie czasu, stopniowo ulegała konwencjonalizacji, zatracając tym samym moc sprowadzenia pomyślności na osobę witaną dobrym słowem. Pozbawienie formuły powitalnej roli zaklęcia bynajmniej nie oznacza, że w konfrontacji ze współczesnością intencje życzące przestały obowiązywać. Potrzeba zaklinania rzeczywistości realizowana jest obecnie przez nową formułę dobrego dnia, która stanowi niemal dokładne powielenie poprzedniej. Różnica polega na tym, że wypowiadana jest w końcowej fazie kontaktu, zastępując lub dopełniając konwencjonalną frazę pożegnalną do widzenia.

Tradycyjne formuly życzeniowe wypowiadane przy specjalnych okazjach, jak też towarzyszące im symboliczne gesty — pocałunki, uściski — zachowują niezmienną postać, intencję oraz moc sprawczą, zwłaszcza jeśli wpisują się w scenariusz rytuału, przebiegającego $\mathrm{w}$ odpowiednim miejscu i czasie, $\mathrm{z}$ udziałem przedmiotów, które jako atrybuty sacrum (opłatek wigilijny, choinka, poświęcone pokarmy, pisanki) wskazują na jego obecność w tle sceny, dzięki czemu życzenia mogą się urzeczywistnić. Za nacechowany szczególną mocą sprawczą uważa się czas Narodzenia Pańskiego oraz Wielkiej Nocy — w obu wypadkach znamionujący początek wielkiej zmiany. Błogosławieństwo niebios przynosi światu odnowę, czemu zawdzięczają swą moc życzenia zdrowia, pomyślności i dostatku, składane w czasie świętym. Obdarzaniu się dobrym słowem towarzyszą rytualne uczty. Zarówno powinszowania, jak i obrzędowe potrawy (naznaczone symboliką sakralno-apotropaiczną) stanowią dar, jednoczący biesiadników. W kulturze ludowej zwyczaj dzielenia się opłatkiem i składania życzeń nie ogranicza się do członków rodziny, ale obejmuje również zwierzęta, do których — zależnie od gatunku — kierowane były odpowiednie formuły życzeniowe. Do konia — żeby był zdrowy i dobrze ciągnął, do krowy — żeby dużo mleka dawała, do kur — żeby się dobrze niosły. Dobre słowo wraz z opłatkiem i chlebem należało się w zasadzie wszystkim posiadanym zwierzętom — kotom, psom, owcom, świniom. Zwyczaj rytualnego obdarowywania się słowem i pożywieniem (zwłaszcza chlebem) ma charakter symboliczny — poczucia zjednoczenia się z całym odnowionym światem (ludzkim i zwierzęcym) w przeżywaniu łączności z sacrum w akcie błogosławieństwa i cyklicznego odradzania się życia (Kraczoń 2014, s. 83-84).

Do archetypów wierzeniowych należy też czas przełomu - Nowego Roku. Magiczną moc zyskują życzenia złożone o północy, w momencie gdy odchodzący stary rok ustępuje miejsca nowemu. Podczas gdy życzenia świąteczne i noworoczne kierowane są do szerokiego kręgu odbiorców (członków rodziny, bliższych i dalszych znajomych), dni urodzin i imienin stanowią czas szczególny dla jubilatów i solenizantów. Niemniej formuły życzeń — bez względu na okazję 
— zawierają te same składniki podstawowe, jakimi są zdrowie, szczęście i pomyślność. Stanowią one ciąg wzajemnie warunkujących się wartości, z których na pierwsze miejsce wysuwa się $z$ drowie.

Bezpośredni związek zdrowia z życiem stawia je na najwyższym stopniu w hierarchii słów-zaklęć, które funkcjonują również w innych sytuacjach. Życzenie na zdrowie używane jest $\mathrm{w}$ różnych okolicznościach: przy wznoszeniu toastów, kichaniu (jako werbalny relikt dawnego zwyczaju zażywania tabaki — dla zdrowia), a także jako „dobre słowo” w odpowiedzi na podziękowanie za datek lub darmowy poczęstunek (niech idzie na zdrowie).

Symboliczny charakter toastów wpisuje się w konceptualizację biesiady i uczty jako magicznego rytuału jednoczącego uczestników przez przyjmowanie daru jedzenia i okazywanie wzajemnej życzliwości przez przepijanie do kogoś, picie zdrowia, picie za zdrowie. Spetnianie toastu wskazuje na performatywny charakter życzenia, zwykle adresowanego do konkretnej osoby (zdrowie gospodarza, zdrowie pani domu, zdrowie solenizanta, jubilata, zdrowie młodej pary itp. - stosownie do okoliczności). Towarzyszący życzeniom gest wznoszenia kielicha do góry (wznosić toast za kogo), niekiedy w połączeniu z powstaniem i wygłoszeniem dłuższej oracji, nadaje tej czynności uroczysty charakter, co jest zaledwie śladem dawniejszego ceremoniału. W przeszłości toasty stanowiły integralną cześć uczty, przypadającą na jej część końcową. Jak podaje Gloger, do toastów przystępowano dopiero po mięsiwach, a zdrowia (jak określano toasty) ,godziło się spełnić małmazją lub węgrzynem", na stojąco, zachowując odpowiednią ich kolejność. Na ucztach dworskich najpierw „,wznoszono zdrowie Najjaśniejszej Rzeczypospolitej, następnie Króla Jego-Mości, Królowej, potem biskupa, wreszcie najdostojniejszego z gości, duchowieństwa, gospodarstwa" (Gloger 1985: 367; Wolnicz-Pawłowska 2004, s. 162). Na cześć osoby, której zdrowie pito, wiwatowano okrzykiem niech żyje! Staropolski wzorzec wznoszenia toastów i wiwatowania uległ wprawdzie znacznemu ograniczeniu, niemniej podstawowa struktura wraz z hierarchicznie zachowaną kolejnością adresowania toastów utrzymała się do dziś w sytuacjach uroczystych.

Do form grzecznościowych zamykających kontakt należą pozdrowienia kierowane do rodziny osoby, z którą się żegnamy (typu pozdrów żonę, rodzinę itp.). Słowa pozdrowień używane są też w zakończeniach listu (łaczę serdeczne pozdrowienia, pozdrawiam itp.), a także stanowią standardową, acz niewyszukaną treść kartek pocztowych, wysyłanych z wakacji (pozdrowienia z wakacji przesyła X).

\section{Dobre słowo jako dar w rytuale kolędowania}

Szczególnym sposobem operowania „dobrym słowem” jako obrzędowym darem wymiennym jest ludowy zwyczaj kolędowania. Kolęda życząca to najbardziej rozbudowany poetycki tekst magiczny, przekazywany bezpośrednio w for- 
mie śpiewanej lub recytowanej podczas rytualnego obchodzenia domostw przez grupy kolędnicze ${ }^{6}$. Specyfiką tekstu jest jego sceniczność oparta na trójdzielnej konstrukcji, składającej się z części wstępnej — zapowiedzi kolędowania i prośby o przyjęcie, części głównej - powinszowania skierowanego do konkretnego domownika, zakończonego „przymówką o datek” oraz podziękowania za poczęstunek lub dar (Niebrzegowska-Bartmińska 2007, s. 196-199), np. „Przyszliśmy tu po kolędzie, niechaj będzie / Bogu wieczna cześć, chwała! / A niechaj to gospodarza nie obraża, / By jego łaska trwała! / Czym cię nagrodzimy? / Że zdrowia życzymy, wiernie służymy" (Kotula 1970, s. 254).

Istotnym elementem scenariusza jest czas, w którym odbywają się obrzędy. W tradycji ludowej jest to okres Bożego Narodzenia (i Nowego Roku) oraz Wielkiej Nocy ${ }^{7}$. W obu wypadkach jest to czas szczególny — początku i końca — zarówno w wymiarze religijnym, jak i kosmicznym, uwarunkowanym rytmem życia przyrody ${ }^{8}$. Cud Pańskiego Narodzenia oraz Zmartwychwstania w kolędowych tekstach stanowi wierzeniową podstawę życzeniowego, niczym nieograniczonego kreowania rzeczywistości. Choć intencje i treść życzeń oraz ich wartość aksjologiczna są w bożonarodzeniowo-noworocznych i wiosennych kolędach zbliżone, podobnie jak ich adresaci, niemniej dadzą się wyodrębnić pewne charakterystyczne cechy dla każdej z tych grup.

Z kolędowaniem w okresie Godów (jak w ludowej tradycji określa się czas Bożego Narodzenia i Nowego Roku trwający do Trzech Króli) wiąże się przekonanie o szczególnej łasce niebios, jaka w tym czasie udziela się całemu światu, co uwidacznia nazwa obrzędu chodzenie po szczodrokach, samych kolędników szczodraki, szczodrorze (Bartmiński 1986b), s. 61-66; 2002, s. 81), jak też specjalnie na tę okazję pieczonych bułek, zwanych szczodrakami, którymi ich częstowano. Podstawę obrzędu stanowiło szczodre wzajemne obdarowywanie się

${ }^{6}$ Kolęda jako gatunek tekstu oraz jej funkcjonowanie w kulturze ludowej zostały omówione w szeregu studiów Jerzego Bartmińskiego (1986a, 1986b, 1986c), Stanisławy Niebrzegowskiej-Bartmińskiej (2007), Jana Adamowskiego (1997, 1998, 2001), Dobrosławy Wężowicz-Ziółkowskiej (1983).

7 Jerzy Bartmiński kolędowaniu przypisuje trzy rodzaje świąt: Bożego Narodzenia, Nowego Roku i Wielkiej Nocy (2002, s. 25), a Stanisława Niebrzegowska-Bartmińska wydziela dwa okresy kolędowania: zimowy i wiosenny (2007, s. 196).

8 Słowiański zwyczaj składania życzeń w okresie nowego roku oraz wiosną sięga czasów przedchrześcijańskich, jego elementy widoczne są w treści powinszowań, ukierunkowanych na dobrobyt, urodzaj. Natomiast kolęda jako pieśń religijna o Narodzeniu Pańskim rodowodem sięga średniowiecza (np. Anioł pasterzom mówit), jej „,wiek złoty” przypada na okres baroku (z tego okresu pochodzą popularne do dziś kolędy A wczora z wieczora, Przybieżeli do Betlejem pasterze oraz liczne pastorałki). Wiek XVIII upamiętniła kolęda Franciszka Karpińskiego Bóg się rodzi uznana za arcydzieło gatunku, a wiek XIX pozostawił po sobie równie piękny tekst Mizerna cicha Teofila Lenartowicza. Dowodem na to, że kolędy na stałe wpisały się w kulturę polską, są liczne warianty powstałe w okresie II wojny światowej (Adamowski 1997), zwłaszcza w obozach zagłady, np. oświęcimska kolęda-skarga (Bartmiński, Sulima 1991, s. 166), a także pochodzące z czasów współczesnych kolędy solidarnościowe z okresu stanu wojennego. 
- w wymiarze duchowym (funkcję tę pełniła wyśpiewywana kolęda życząca) i materialnym (w formie datku dla kolędników — jedzenia, wódki, pieniędzy). Zjednoczenie nieba z ziemią, przez zesłanie daru w postaci Syna Bożego, stwarza warunki do ogólnego zbratania się ludzi, bez względu na stan, religię czy pochodzenie. Z kolędą chodzono do sąsiadów, do dworu i do żydowskiej karczmy, o czym świadczą teksty powinszowań adresowane do gospodarza, gospodyni, ich dzieci, do dziedzica i arendarza. Kolędowanie — jak pisze Jerzy Bartmiński to przedłużenie jasełkowego misterium bożonarodzeniowego, które ,pozostaje w pamięci społecznej jako wzorzec regulujący zachowania świąteczne i stwarzający kulturową ramę dla kolędowania” (Bartmiński, Sulima 1991, s. 170).

W narracjach kolęd bożonarodzeniowo-noworocznych cudowność nowiny z szopy betlejemskiej przeniesiona zostaje w miejsce obrzędu, nadając projektowanym wydarzeniom nadzwyczajne właściwości. Jeśli na scenie w roli głównych bohaterów występują osoby boskie i święte, to — zgodnie z intencją winszującą — ich obecność sprawia, że gospodarzom „darzy się” w polu, oborze i w komorze, a kolędnicy tylko relacjonują zdarzenia. Tak dzieje się w kolędzie Bóg się szerzy. Gospodarzowi mnoży się trzoda: byczki o złotych rogach, konie o złotych grzywach, a także świnie o złotych ryjach, które wydobywają z ziemi bryły złota, by ulać z nich kielich na przyjęcie Pana Jezusa, przybywającego do gospodarza wraz z aniołami po kolędzie ${ }^{9}$. W podobnych tekstach Pan Jezus w towarzystwie świętych (św. Pawła, św. Szczepana, św. Jana) pracuje na jego polu, Matka Boska przygotowuje im śniadanie, sam Pan Bóg zaprasza na poradeczek, a na polu gospodarza mnożą się kopki siana, stodoły zapełniają się zbożem (Niebrzegowska-Bartmińska 2007, s. 234-239).

W scenariuszach (zwłaszcza wiosennych) bez osób boskich i świętych sacrum — jako źródło mocy — występuje w tle sceny, natomiast miejsce centralne zajmują adresaci życzeń, którzy — mocą wyśpiewanego słowa — zostają wciągnięci w scenę jako odbiorcy mocy przez narzucone im przez kolędników role. Akcja toczy się „tu i teraz”, granice między światem realnym a projektowanym zostają zniesione. Nadawcy tekstu kreują cudowną rzeczywistość, odpowiednią do pragnień każdego z domowników. Gospodarz — bogato odziany, liczy pieniądze lub przechadza się po polu między niezliczonymi kopami siana i zboża. Gospodyni w bogatych strojach krząta się po domu i zasobnej komorze, a panna — przedstawiana w scenerii zalotno-weselnej: w sadku, w altanie, oczekuje na kawalera, poi jego konika lub siedzi przy „cisowym stole” — w roli pani młodej.

9 „Nowe lato, szczodre lato / Nowy wieczór, szczodry wieczór / A wyjdźże gospodarzu / Bóg się szerzy w twym podwórzu / Krówki ci się pocieliły / Trzysta byczków popłodziły / A te byczki białe nogi / Białe nogi, złote rogi [...] / A te źrebocki białe nogi, złote grzywy [...], A te wieprzki białe nogi, złote ryje [...] ryły, ryły i wyryły / i wyryły złote bryły / Dzież my to złoto podziejemy? / Do złotnika zaniesiemy / Uleje nam złoty kielich [...] Któż tym kielichem pijać będzie? / Sam Pan Jezus po kolędzie / Sam Pan Jezus z aniołami / Najświętsza Panienka ze świętymi” (Bartmiński, Sulima 1991, s. 27-28). 
Syn gospodarza kreowany jest na dzielnego wojaka lub myśliwego, któremu po powrocie do domu będzie wyswatana żona. Podobnie arendarz i jego domownicy — żona, syn i córka, ubrani w bogate stroje — żyją w dostatku i szczęściu (Niebrzegowska-Bartmińska 2007, s. 235-237).

Przekaz życzeniowy w kolędach zimowych i wiosennych oscyluje wokół tych samych wartości: zdrowia, urodzaju, bogactwa. Obrzęd kolędniczy, podobnie jak rytuał wigilijnej wieczerzy i wielkanocnego śniadania, stawia na równi wartość daru słowa $z$ darem jedzenia. Poczęstunek (lub ekwiwalent pieniężny, znacznie późniejszy) szykowany dla kolędników w podziękowaniu za życzenia stanowi wzorzec zachowań rytualno-magicznych, mający na uczestników sprowadzić szczęście poprzez wymianę darów, zgodnie z zasadą „daj, aby i tobie dano”.

\section{Rytuały chroniące działanie dobrego słowa przed ingerencją sił nieczystych}

Magiczne praktyki stwarzania pomyślnej rzeczywistości za pomocą „dobrego słowa" wymagały zaangażowania różnych środków, by uzyskać dostęp do sił nadprzyrodzonych. Wejście w kontakt z rzeczywistością „nie z tego świata” oznaczało otwarcie się zarówno na działanie łaski, jak i ingerencję sił demonicznych, wrogich człowiekowi, gotowych pomieszać szyki i odwrócić bieg wydarzeń, sprowadzając na człowieka nieszczęście. Przed niepożądanymi działaniami złych duchów broniły rytuały ochronne - werbalne i gestyczne, jak też różnego rodzaju środki zapobiegawcze.

Funkcje ochronne w obrzędzie kolędniczym pełniły maski i przebrania kolędników, by złe moce wzięły ich za swoich. Wśród przebierańców nie zabrakło śmierci, diabła i anioła - jako prototypowych mieszkańców zaświatów, a także przedstawicieli innych grup społecznych i narodowościowych — dziada, Żyda, Cygana, Niemca, Węgra oraz księdza. Przypadała im rola mediatorów między „tym” (swoim) a „tamtym światem” (obcym), gdzie znajdowało się źródło mocy, do której - jako obcy - mieli lepszy dostęp (Adamowski 2008, s. 194-195; Zając 2004, s. 46; Masłowska 2012c, s. 298). Przebrania — oprócz funkcji ochronnej - mają też bogate znaczenie symboliczne. Maski zwierzęce, przedstawiające silnych samców (byka, turonia, koguta, niedźwiedzia) symbolizują płodność, bogactwo i dostatek, potęgując siłę sprawczą słowa. Jednocześnie zaś wszystkie postacie przebierańców z korowodu kolędniczego wpisywały się w ogólną semantykę i wartość aksjologiczną Bożego Narodzenia i Wielkiej Nocy — połączenia nieba z ziemią, świata ludzi i zwierząt, zwycięstwa życia nad śmiercią i dobra nad złem.

Działania ochronne obejmują w zasadzie wszystkie sytuacje, w których „dobre słowo" ma moc sprawczą. Funkcję zapobiegawczą pełnią powszechnie stosowane zakazy dziękowania za życzenia, podyktowane obawą przed „lichem”, które 
spowoduje, że się nie spełnią. Kod ochronny realizowany jest też w zakazach głośnego wypowiadania pragnień, okazywania zbytniej radości z pomyślnych wydarzeń oraz życzeniu sukcesu przed jego osiągnięciem. Służą temu specjalne formuły w postaci quasi-złorzeczeń typu połam nogi, złam pióro (wypowiadane przed egzaminem), czemu towarzyszą niekiedy specjalne gesty, jak kopniak na szczęście czy trzymanie kciuków.

\section{Podsumowanie}

Kody zachowań sprawczych i ochronnych opierają się na odmiennych podstawach. Błogosławieństwa, życzenia, pozdrowienia — zarówno w formie werbalnej, jak i symbolicznych gestów - przywołują pamięć mitu stworzenia — słowa „stań się” oraz boskiego tchnienia życia. Natomiast źródło zakazów wypowiadania życzeń, podziękowań za „dobre słowo”, jak też eufemistycznych pseudozłorzeczeń tkwi w archaicznych przekonaniach, że ,licho nie śpi”, gotowe zawsze wtargnąć w życie człowieka i pokrzyżować jego plany. Świadczy o tym zabobonne podporządkowanie się powszechnie obowiązującej zasadzie w postaci formulicznego zakazu nie budź licha czy jego ekwiwalentów nie chwal dnia przed zachodem słońca, nie dziel skóry na niedźwiedziu.

Dziedzictwo mitycznego myślenia stanowi mocne podstawy psychologiczne kulturowego wzorca, choć selekcja przekazywanych z przeszłości wartości, ich hierarchizacji znajduje wyraz w zmieniających się formach działań werbalnych i pozawerbalnych. Żywotność kultury polega na stałej zdolności odradzania się przez odwołanie się do kontekstów obecnych w zbiorowej pamięci. Stałą wartością, stanowiąca jądro semantyczne dobrych życzeń i działań zapobiegawczych, jest zdrowie i jego ochrona. Preschematy wyobrażeniowe - CAŁOŚĆ, WIĘŹ, KONTROLA, obecne w pojęciach z nimi związanych (całować, zdrowie, cały) - występują w formułach życzeń oraz praktykach magicznych z preschematem SIŁY. Natomiast samo dobre słowo — zarówno ze względu na działanie (wypowiadanie formuły powitalnej i pożegnalnej), jak i czas otwierający i zamykający pewien przedział (urodziny, Nowy Rok, Święta Bożego Narodzenia i Wielkiej Nocy) — mieści się w preschematach POCZĄTKU i KOŃCA.

\section{Bibliografia}

Adamowski J. (1997), Kolędy okresu II wojny światowej, „Twórczość Ludowa” 1, s. 4-8. Adamowski J. (1998), Kolędy z okolic Janowa Lubelskiego, „Twórczość Ludowa” 4, s. 1-6. Adamowski J. (2001), Biłgorajska kolęda gospodarska o trzech furmanach, „Twórczość Ludowa” 2, s. $11-13$. 
Adamowski J. (2008), Postać obcego w polskich obrzędach dorocznych. Od obcości do wspólnoty, „Etnolingwistyka. Problemy Języka i Kultury” 20, s. 191-200.

Bartmiński J. (1986a), „Bóg się szerzy”. Przykład chrystianizacji noworocznej kolędy ludowej, [w:] Biblia a literatura, red. S. Sawicki, J. Gotfryd, Lublin, s. 479-497.

Bartmiński J. (1986b), Kolęda i jej odmiany gatunkowe, [w:] Kolędowanie na Lubelszczyźnie, red. J. Bartmiński, C. Hernas, Wrocław, s. 78-184.

Bartmiński J. (1986c), Wszystko się zmieniło, jak nigdy nie było, [w:] Kolędowanie na Lubelszczyźnie, red. J. Bartmiński, Cz. Hernas, Wrocław, s. 5-10.

Bartmiński J. (2002), Polskie kolędy ludowe. Antologia, Kraków.

Bartmiński J. (2009), Pocałunek ziemi. Semantyka gestu, [w:] Stereotypy mieszkaja w języku, Lublin, s. 149-156.

Bartmiński J., Sulima R. (1991), Kolędy polskie, Warszawa.

Campbell J. (1994), Potega mitu. Rozmowy Billa Moyersa z Josephem Campbellem, oprac. B.S. Flowers, przeł. I. Kania, Kraków.

Cirlot J. E. (2001), Stownik symboli, przeł. I. Kania, Kraków.

Długosz-Kurczabowa K. (2005), Stownik etymologiczny języka polskiego, Warszawa.

Eliade M. (2000), Traktat o historii religii, przeł. J. Wierusz-Kowalski, Warszawa.

Engelking A. (1991), Rytualy słowne w kulturze ludowej. Próba klasyfikacji, [w:] Język a kultura, t. 4. Funkcje języka i wypowiedzi, red. J. Bartmiński, R. Grzegorczykowa, Wrocław, s. 75-85.

Forstner D. (1990), Świat symboliki chrześcijańskiej, przeł. W. Zakrzewska, P. Pachciarek, R. Turzyński, Warszawa.

Gloger Z. (1985), Encyklopedia staropolska ilustrowana, t. 1-4, Warszawa, przedruk fotooffsetowy wydania z 1900-1903.

Johnson M. (1990), The Body in the Mind. The Bodily Basis of Meaning, Imagination and Reason, Chicago-London.

Kardela H. (1998), Profilowanie a kategorie podmiotu i dopetnienia w gramatyce R. Langackera, [w:] Profilowanie w języku i w tekście, red. J. Bartmiński, R. Tokarski, Lublin, s. 79-90.

Kopaliński W. (1990), Stownik symboli, Warszawa.

Kotula F. (1970), Hej leluja. Czyli o wygasajacych starodawnych pieśniach kolędniczych w Rzeszowskiem, Warszawa.

Kraczoń K. (2014), Zwyczajowe i obrzędowe gesty towarzyszace spożywaniu pokarmów, [w:] Tam na Podlasiu, t. 4. Pożywienie - czyli coś dla ciała i coś dla ducha, red. J. Adamowski, M. Wójcicka, Wola Osowińska, s. 75-88.

Krzeszowski T. (1994), Parametr aksjologiczny w przedpojęciowych schematach wyobrażeniowych, „Etnolingwistyka” 6, s. 29-51.

Krzeszowski T. (1999), Aksjologiczne aspekty semantyki językoznawczej, Torun.

Langacker R. (2009), Gramatyka kognitywna, Kraków.

Libura A. (2000), Wyobraźnia w języku. Leksykalne korelaty schematów wyobrażeniowych Centrum -Peryferie i Sity, Wrocław.

Linde S.B. (1951), Słownik języka polskiego, t. 1-6, Warszawa, wydanie III fotooffsetowe.

Lurker M. (1994), Przestanie symboli w mitach, kulturach i religiach, przeł. R. Wojnakowski, Kraków.

Marczewska M. (2014), Językowo-kulturowy obraz zdrowia w polszczyźnie, [w:] Wartości w językowo-kulturowym obrazie świata Stowian i ich sąsiadów, t. 3. Problemy eksplikowania i profilowania pojęć, red. I. Bielińska-Gardziel, S. Niebrzegowska-Bartmińska, J. Szadura, Lublin, s. $151-168$.

Masłowska E. (2004), Kognitywne ścieżki zdrowia, [w:] Życie i zdrowie człowieka w tradycji i kulturze polskiej, red. ks. W. Bołoz, E. Wolnicz-Pawłowska, Warszawa, s. 179-193.

Masłowska E. (2012a), Ludowe stereotypy obcowania świata i zaświatów w języku i kulturze polskiej, Warszawa. 
Masłowska E. (2012b), Fantomy pamięci. Pamięć semantyczna pocatunku, [w:] Tradycja dla wspótczesności. Ciagłość i zmiana, t. 6. Pamięć jako kategoria rzeczywistości kulturowej, red. J. Adamowski, M. Wójcicka, Lublin, s. 129-141.

Masłowska E. (2012c), Pozytywne schematy destrukcji w relacjach z zaświatami, [w:] Wartości w językowo-kulturowym obrazie świata Stowian i ich sasiadów, red. M. Abramowicz, J. Bartmiński, I. Bielińska-Gardziel, Lublin, s. 289-303.

Nahodil O. (1991), Tradycja jako definiens kultury, „Lud” 74, s. 5-17.

Niebrzegowska-Bartmińska S. (2007), Wzorce tekstów ustnych w perspektywie etnolingwistycznej, Lublin.

Sinka T. (1994), Zarys liturgii, Kraków.

Sławski F. (1954-1982), Słownik etymologiczny języka polskiego, t. 1-5, Kraków.

Sławski F. (1983), Stownik etymologiczny języka polskiego, z. 1 (A-Czar), Kraków.

Szacki J. (1971), Tradycja. Przegląd problematyki, Warszawa.

Tabakowska E. (red.) (2001), Kognitywne podstawy języka i językoznawstwa, Kraków.

Wężowicz-Ziółkowska D. (1983), Świat wartości kolędy życzacej, „Literatura Ludowa” 6, s. 31-41.

Wolnicz-Pawłowska E. (2004), ,Ślachetne zdrowie..." - zdrowie i życie człowieka w języku staropolskim $i$ we wspótczesnej polszczyźnie, [w:] Życie i zdrowie czlowieka w tradycji i kulturze polskiej, red. ks. W. Bołoz, E. Wolnicz-Pawłowska, Warszawa, s. 179-193.

Wójcicka M. (2014), Pamięć zbiorowa a tekst ustny, Lublin.

Zając P. (2004), O zaświatach niedalekich i cudach nienadzwyczajnych. Nadprzyrodzone w kulturze ludowej na przykładzie Huculszczyzny, Kraków.

\section{Good words as a magical text: Wishes, greetings, blessings}

\section{Summary}

The article is devoted to cultural patterns of creating favourable reality by means of magic words and gestures. The analysis of cognitive settings of wishing scenarios is focused on the semantic memory of symbols (referring to a myth and reactivated in the ritual of blessing or expressing good wishes), lexical items (etymological meaning and connotation) and axiology — the principal criterion of selection which explains the use of traditional patterns and modifications of the code. The author explores the semantic core of wishing rituals preserved in stereotypical patterns of cultural memory and examines their linguistic manifestations.

Keywords: blessing, wishes, kiss, symbolism, ritual, cognitive studies, semantics 